\title{
Financing of sanitation services in the slums of Kampala and Dar es Salaam
}

\author{
John Bosco Isunju ${ }^{1^{*}}$, Samuel Etajak $^{1}$, Beatrice Mwalwega ${ }^{2}$, Richard Kimwaga $^{2}$, \\ Peter Atekyereza $^{3}$, William Bazeyo ${ }^{1}$, John C. Ssempebwa ${ }^{1}$ \\ ${ }^{1}$ Disease Control and Environmental Health Department, School of Public Health, College of Health Sciences, Makerere University, \\ Kampala, Uganda; ${ }^{*}$ Corresponding Author: ibosco2001@yahoo.com, isunju@musph.ac.ug \\ ${ }^{2}$ Department of Water Resources Engineering, College of Engineering and Technology, University of Dar es Salaam, Dar es Salaam, \\ Tanzania \\ ${ }^{3}$ Department of Sociology, College of Humanities and Social Sciences, Makerere University, Kampala, Uganda
}

Received 22 February 2013; revised 24 March 2013; accepted 9 April 2013

Copyright (C) 2013 John Bosco Isunju et al. This is an open access article distributed under the Creative Commons Attribution License, which permits unrestricted use, distribution, and reproduction in any medium, provided the original work is properly cited.

\section{ABSTRACT}

This paper presents an assessment of the extent and conditions under which private financing can be a realistic approach for sanitation in slums. It is based on a cross-sectional study comparing two slum communities in East Africa, where 250 households from Bwaise III in Kampala, Uganda and 379 households from Temeke in Dar es Salaam, Tanzania were interviewed in 2010. Also, 10 key-informant interviews and 8 focus group discussions were conducted in addition to field observations. Findings show that majority (85\%) of households used unimproved, private-shared pit latrines. These privately owned latrines had many structural shortfalls besides poor operation and maintenance while the public latrines provided by third-party were structurally sound but were underutilized in residential slum neighborhoods. This is attributed to the presence free or at least cheaper alternatives which the community members preferred instead of paying per-visit user-fees. For the few who were willing to pay, willingness to pay was positively associated with the presence of a facility User committee and having been sensitized. In this context, a combination of these factors made cost recovery as well as operation and maintenance very minimal. The poor status of privately owned shared pit latrines matched the limited income levels of households. Similarly, cost recovery for public facilities was dependent on the number of users who were willing to pay: the more the users, the more the cost recovery. A combination of private and public financing is thus necessary to fund different but complementary aspects of sanitation in slums.

Keywords: Slums; Sanitation; Public; Private; Financing Approaches

\section{INTRODUCTION}

About 2.6 billion people globally have no access to improved sanitation and the resulting diarrhea kills at least 1.2 million children below five years annually [3]. Poor sanitation causes economic losses associated with the direct costs of treating sanitation-related illnesses and lost income through reduced or lost productivity [4]. Public financing for sanitation has become increasingly insufficient to meet the current sanitation gap, especially in Sub-Saharan Africa [5-7]. Research indicates that leveraging household and market-based resources to invest in sanitation improvements is a promising measure [6, 8 -11]. The argument is that private financing for sanitation needs to be increased. In practice however, this financing approach may be subject to context specific obstacles such as limited incomes, peoples' spending priorities, and existing social structure among other factors [7]. Majority of slum dwellers are poor. They endure many deprivations and are faced with various needs amid the sanitation situations they live in [12], and as a result, many may be unable or unwilling to invest in improving sanitation. Some rented house owners (landlords) in slums for example, would rather construct another bedroom than a latrine [13]. Studies in Senegal, Mozambique, Bangladesh and Ecuador show that financing onsite sanitation for the poor is unsustainable unless the public sector continuously contributes or some form of external financing is provided [14]. 
At a local scale, financing needs vary depending on the sanitation technology, and whether the fecal sludge generated is disposed of on-site or at an off-site treatment facility. On-site sanitation, specifically pit latrines shared among several households is the dominant means of human waste management in slums [1,15-17]. Limited financing is a major hindrance to replication, scale up and sustainability of promising financing approaches. It is essential to establish and quantify all costs in the life cycle of a facility; establish who pays, how much, in what way, and for what components. The lack of or inadequacy in financing of all cost components of a sanitation system creates bottle necks that ultimately affect the quality and coverage of sanitation services [7,18]. This paper presents the extent to which and under what conditions private financing is a realistic approach for sanitation in slums. The analysis is based on two study areas in East Africa: Bwaise III in Kampala, Uganda and Temeke in Dar es Salaam, Tanzania.

\subsection{Financing the Investment Cost}

Cost recovery is generally considered as a sustainable financing strategy in water supply investments [19-21]. But, unlike water supply, sanitation services suffer the problems of uncertain demand and limited scope for revenue generation [22]. From the demand-side, low prevalence of improved latrines can be explained by affordability constraints associated with low household incomes and by the higher capital costs associated with constructing such facilities [23]. Considering the level of investments associated with different sanitation options against the life cycle costs [18], the more expensive the option in terms of capital investment (e.g. sewerage) the more it is subsidized using public funds and the less the recurrent costs on the users. Conversely, the cheaper the option in terms of capital investment (e.g. household latrine) the less it is subsidized and the more the recurrent costs [24]. It is essential to identify the sources and financing approaches for the various components in the life cycle of a facility by identifying who pays, how much, in what way, and for what. In many countries, investment in on-site sanitation is a private responsibility, particularly individual households. However, given that the bulk of poor households can hardly afford to cover full investment cost up-front [25], seldom, public funds in form of subsidies are used to incentivize investments. But even with subsidized investment cost, households have to meet the high recurrent cost of operation and maintenance especially in the urban slum settings. When a pit latrine is full, there are only two options: stop using it and construct a new latrine if there is available space and funds, or empty it $[15,26]$. Many subsidized latrines in slum areas operate only for a short period of time before they are closed off because of poor operation and maintenance $[27,28]$. In measuring progress on sanitation improvements emphasis has been on physical outputs such as provision of new facilities with only little or no attention on outcomes; primarily the continued use and maintenance of facilities.

\subsection{Financing the Operation and Maintenance Cost}

Operation and maintenance costs in this context relate to the regular requirements necessary for efficient performance of a sanitation facility to serve its intended purpose. Such costs may include pit emptying, paying a care taker (where applicable), providing toilet paper, water and soap for cleaning, hand washing and flushing in case of facility waterborne systems [17]. Operational costs may also include lighting for night users that is: electricity, torch, candles or kerosene lamp. Unlike in rural areas where a household owns and maintains a sanitation facility, in many urban poor settlements, several households may share a latrine stance. A recent study in Kampala slums reported that one stance of a public latrine was shared by up to 82 people [25]. Although in such cases, the responsibility of operation and maintenance would be the on all the users, shared usage does not necessarily engender a sense of shared responsibility or a practical response from users [29]. Although operation and maintenance exert no direct financial burden on the local authority, there are often indirect costs for monitoring and regulation or subsidies that need to be financed [22]. These indirect costs however are usually under estimated or ignored both in public and private financing approaches.

\subsection{Potential Financing Approaches for On-Site Sanitation}

Financing for on-site sanitation could be sourced using three financing approaches: purely private, combination of private and public, or purely public [14,17]. There are potential advantages and risks associated with each of the above financing approaches. The present article analyses the potential of private financing for investment, operation and maintenance of existing sanitation facilities in two urban slums.

\section{METHODOLOGY}

\subsection{Study Area}

Two slum communities were studied: Bwaise III parish in Kampala district, Uganda and Temeke, Dar es Salaam, Tanzania. These were selected because they were typical slum settlements facing fairly comparable challenges such as overcrowding, low socioeconomic status, majority of households in rented accommodation, shared 
latrine facilities, high water table and flooding among others.

Bwaise III: Bwaise III Parish is one of 24 parishes in Kawempe Division of Kampala district. Its population is approximately 50,000 people, with the majority living in crowded housing rental units amidst poor environmental sanitation conditions. The parish has an area of 57 ha and is divided into six local administrative zones namely: Kamalimali, Bokasa, Bugalani, St. Francis, Katoogo and Kawaala. The study was done in five zones excluding Kawaala which was largely part of a road reserve. A representative sample of 250 households was randomly selected from a targeted total of 3001 households and proportionately distributed across the five zones based on the total number of households in each zone.

Temeke: Four wards considered slum settlements were purposively selected out of the 24 wards of Temeke municipality, Dar es Salaam. These were: Tandika, Mbagala Kuu, Mbagala and Makangarawe. A representative sample of 379 households was randomly selected from a targeted total of 30,729 households and proportionately distributed across the four wards based on the total number of households in each ward.

\subsection{Study Design}

The study was cross sectional and employed both quantitative and qualitative methods of data collection. Study units were households and respondents were household heads or a responsible adult found at home at the time of survey. Semi-structured questionnaires, observation checklists, photography, focus group discussions and key informant interview guides were used in collecting the data. Stakeholders in the sanitation subsector, including local leaders, Non-Governmental Organizations/ Community-Based Organizations (NGO/CBOs), health personnel and resource persons in the community were interviewed as key informants. Specifically, focus was on socio-economic status of the study populations, sanitation options, investment costs, operation and maintenance costs including method and cost of pit emptying, and financing approaches used for private facilities and for public facilities. Willingness to pay for public facilities was also assessed.

Data management and analysis: For quantitative data, categorical variables such as sex, level of education, occupation and income levels were summarized using proportions, percentages and frequencies. Continuous variables such as age were summarized using mean, median, range and standard deviation. Bivariate analysis was done to determine association between independent and dependent variables. Odds Ratios (ORs) were used for statistical associations at $95 \%$ confidence interval considering statistical significance for $\mathrm{p}$-values less than
0.05. Qualitative data were analyzed by coding/grouping related responses on a master sheet and the findings integrated with the quantitative data during presentation of findings in quotes and narratives.

Quality control: To ensure quality, the following measures were undertaken: two assistants in each study sites were trained on data collection and continuously assessed. The research assistants were fluent in English and local languages and had experience in community data collection. For comprehension, acceptability and appropriateness to collect the required data, questionnaires were pre-tested and field editing was done to ensure completeness and correctness of data.

Ethical consideration: This study was conducted according to the Helsinki ethical principles of voluntary participation and informed consent for research on human subjects. An introductory paragraph on the first page of the survey questionnaire explained the purpose of the study, confidentiality, voluntary participation, anonymity, withdrawal, and consent to participate. Participants were free to withdraw from the study if they so felt uncomfortable. A willing participant responded to questions asked by the research assistant who administered the questionnaire. To ensure anonymity, codes instead of names were used to identify respondents.

\section{RESULTS AND DISCUSSION}

Socio-economic status: About $82 \%$ of respondents in Bwaise III and $60 \%$ in Temeke were self-employed in small businesses such as merchandising, tailoring, masonry, carpentry, boda-boda (motorcycle riders) and food vending and spent about $\$ 1.25$ per day. Less than $5 \%$ in Bwaise III were formally employed with wages/salaries ranging between $\$ 25$ and $\$ 125$ compared to $32 \%$ in Temeke where wages/salaries range between $\$ 50$ and $\$ 226$ monthly. This amount is still slightly more than the minimum wage in Tanzania for other sectors not mentioned in the wage boards which is about \$49 [30]. Income levels in Uganda are worse off than for Tanzania moreover Uganda does not have a legal minimum wage. These low income levels restricted household expenditure to only a few necessities like food, water, and shelter. In both study areas, men were the bread-earners while the women stayed home doing either housework taking care of children or ran a kiosk business near home. In Bwaise III, $73 \%$ of respondents were women of which $20 \%$ did not know the monthly earnings of their spouses. The socioeconomic status in both study sites highlights the communities' limited financial abilities to finance sanitation improvements.

Sanitation options: In both study sites, private shared pit latrine facilities were the common option (85\%). Other options were: Ventilated Improved Pit (VIP) la- 
trines (14\% in Bwaise III) and pour flush latrines (15\% in Temeke) as shown in Figure 1. Over $60 \%$ of private facilities in Temeke did not have washable floor slabs to ease cleaning and majority neither had a roof nor closable doors. These facilities did not ensure enough privacy for users especially women. Approximately $64 \%$ of latrines in Bwaise III had a complete superstructure compared to $25 \%$ in Temeke, although in both cases majority were not clean. It was common practice in Temeke for pour flush latrines to serve also as bathrooms. The bath water would be used to flush the fecal material or to wash the floor. In Bwaise III, bathing would be done in a separate room or enclosure or on the veranda of the house at night. The location of latrine facilities in the two sites varied, with those in Bwaise III being mostly located in the back yard of the living house whereas in Temeke they were mostly situated in front of the living house.

\subsection{Costs Involved}

The study limited the scope to two cost components of investment, and operation and maintenance costs. Investment costs included land acquisition and construction of the facility while operation and maintenance cost included pit emptying, general cleaning and minor repairs.

Investment cost for sanitation facilities: The cost of constructing a sanitary facility depends on several factors

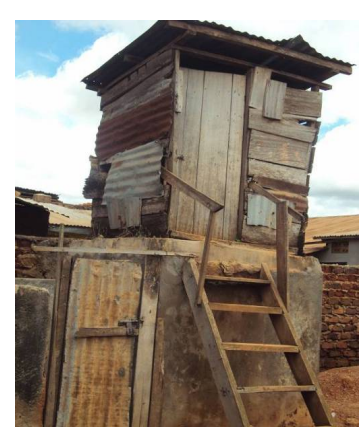

(a)

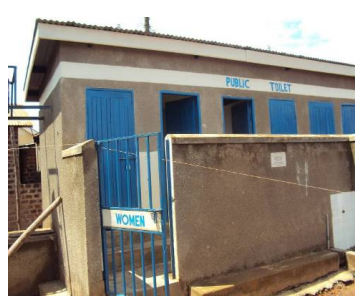

(c)

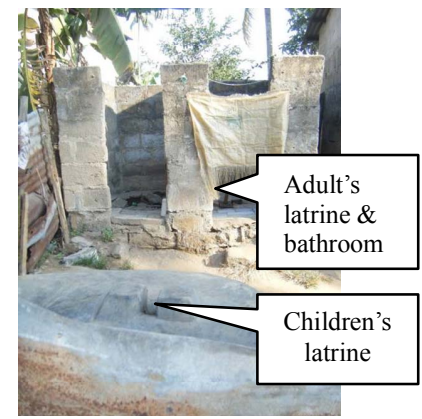

(b)

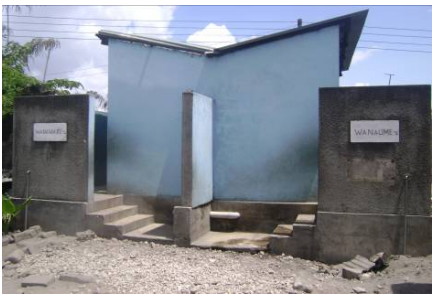

(d)
Figure 1. Status of excreta disposal facilities. (a) Common in Bwaise III, Kampala: raised pit latrines_-Private and shared; (b) Common in Temeke, Dar es Salaam: roofless, doorless pit latrines-Private and shared; (c) Public VIP latrine in Bwaise III-by NGO/Project; (d) Public VIP in Temeke by NGO/ project. such as the type of sanitation technology, building materials, size of the facility in terms of number of stances and capacity of pit, and whether the facility was intended for public or private use. Where the water table is high, the latrine substructure has to be above ground or cement lined all the way from down, which further increases construction costs. A comparison of construction costs for sanitation option in the two sites is summarized in Table 1.

Cost of latrine pit emptying: Pit latrine emptying was on average done twice a year. This rate was considered by latrine owners frequent because of the large number of users. Methods used to empty latrine pits ranged from manual to mechanical. The cost of pit emptying in the two case studies varied considerable depending on the method of pit emptying and service provider (Table 2). Although not formally recognized, manual pit emptying, done by private casual laborers was the cheapest alternative and most widely practiced. The fecal sludge scooped from the latrine pit would be buried adjacent to the latrine. In Temeke, an innovative method for manual pit emptying technology (MAPET) also referred to as sludge Gulper method is used by private pit emptiers to empty latrines in crowed areas not accessible by cesspool emptier trucks. Details on the Gulper technology have been documented [15].

Analysis showed that $56 \%$ of the households in Bwaise III and $60 \%$ in Temeke empty latrine pits manually and burry the sludge next to the latrine. About $30 \%$ of households in Bwaise III used cesspool trucks compared to $25 \%$ in Temeke who used cesspool trucks or MAPET. The practice of illegally discharging latrine sludge into storm drains was mentioned in $2 \%$ and $5 \%$ of households in Bwaise and Temeke respectively. On average, private latrines in both sites are emptied twice a year. The frequency of emptying public facilities de-

Table 1. Cost of constructing sanitation facilities.

\begin{tabular}{|c|c|c|c|}
\hline \multirow{2}{*}{ Type of facility } & \multicolumn{2}{|c|}{ Construction cost $(\$)$} & \multirow{2}{*}{-Funding source } \\
\hline & Bwaise III & Temeke & \\
\hline $\begin{array}{l}\text { Household pit latrine } \\
\text { without permanent } \\
\text { structure }\end{array}$ & $125-335$ & $200-285$ & $\begin{array}{l}\text { Private } \\
\text { owner/landlord }\end{array}$ \\
\hline $\begin{array}{l}\text { Household SanPlat } \\
\text { latrine }\end{array}$ & $418-1250$ & $371-445$ & $\begin{array}{l}\text { Private } \\
\text { owner/landlord }\end{array}$ \\
\hline $\begin{array}{l}\text { Household VIP } \\
\text { latrine or pour flush }\end{array}$ & $418-1045$ & $570-855$ & $\begin{array}{l}\text { Private } \\
\text { owner/landlord }\end{array}$ \\
\hline $\begin{array}{l}\text { Public VIP latrine } \\
(6-8 \text { stances })\end{array}$ & $3344-6270$ & $5130-15,389$ & $\begin{array}{l}95 \% \text { by WaterAid } \\
\& \text { Temeke } \\
\text { Municipality } \\
5 \% \text { community } \\
\text { man power }\end{array}$ \\
\hline $\begin{array}{l}\$ 1=\mathrm{UGX} 2450 ; \\
\mathrm{TZX} 1570\end{array}$ & & & \\
\hline
\end{tabular}


Table 2. Pit emptying methods and cost.

\begin{tabular}{|c|c|c|c|c|}
\hline \multirow{2}{*}{ Method used } & \multicolumn{2}{|c|}{ Pit emptying Cost (\$) } & \multirow{2}{*}{$\begin{array}{l}\text { Service } \\
\text { provider }\end{array}$} & \multirow{2}{*}{ Funder } \\
\hline & Bwaise III & Temeke & & \\
\hline $\begin{array}{l}\text { Motorcycle } \\
\text { (MAPET) (50 lts) }\end{array}$ & $\mathrm{N} / \mathrm{A}$ & 44 & $\begin{array}{l}\text { Private } \\
\text { emptier }\end{array}$ & $\begin{array}{c}\text { Landlords/ } \\
\text { owners }\end{array}$ \\
\hline $\begin{array}{l}\text { Cesspool truck } \\
(20,0001 \text { ts })\end{array}$ & $25.7-42.9$ & $62.9-75.5$ & $\begin{array}{c}\text { Municipal } \\
\text { /Private } \\
\text { emptier }\end{array}$ & $\begin{array}{c}\text { Landlords/ } \\
\text { owner/care } \\
\text { taker }\end{array}$ \\
\hline $\begin{array}{l}\text { Emptying into } \\
\text { another pit } \\
\text { manually or } \\
\text { draining into a } \\
\text { storm water } \\
\text { channel }\end{array}$ & $8.5-17.2$ & $31.4-44$ & $\begin{array}{c}\text { Private } \\
\text { casual } \\
\text { laborers }\end{array}$ & $\begin{array}{c}\text { Landlords/ } \\
\text { owners }\end{array}$ \\
\hline $\begin{array}{l}\$ 1=U G X 2450 ; \\
\text { TZX1570 }\end{array}$ & & & & \\
\hline
\end{tabular}

pended on the size of the pit and number of users which varied considerably. The rate at which a latrine pit fills depends partly on the rate of addition of fecal sludge and partly on the rate of degradation of fecal sludge [31]. Materials that take long or cannot degrade e.g. plastic items, cloth, sanitary pads among others make the pit fill faster and make it difficult to empty.

In Bwaise III, pit emptying was given as one of the major sanitation challenges. Lack of access for emptiers to get to the pit latrines increased the cost if the truck had to park far away from the pit. Sucking sludge over long distances or uphill increases the amount of fuel used in the process. The extra cost is charged on the client in addition to the emptying charge. Due to variation in distance and terrain, the costs of pit emptying varies and is not well regulated for both private and municipal emptiers. Furthermore, fears were raised that structurally weak pit latrines could easily collapse due to suction pressure. Misuse of pit latrines, which involves dumping of materials that cannot be sucked by cesspool emptiers increases the cost of pit emptying because such materials have to be removed first before the emptying. A combination of these challenges explains why majority of households opt to bury the sludge on-site. Elsewhere such complexities have been documented for example: inaccessibility by emptier trucks [32], lack of standardized pit emptying charges [33], weak latrine structures, and misuse of pit latrine by dumping in materials that cannot be sucked by vacuum emptiers $[15,34,35]$.

\subsection{Financing Approaches}

The study limited the scope of financing approaches to the two financing approaches used for the existing facilities in the two study sites; private financing and a combination of public and private financing.

Private financing approach: Household sanitation is a private responsibility, implying the household is pri- marily responsible for financing the capital, operation and maintenance costs. The investment costs and to a large extent pit emptying for private latrines in both study sites were financed by home owners and landlords. Regular cleaning of the latrines was a collective responsibility of all users to participate on a rotational basis, however, for tenants unwilling or unavailable to clean, they would be charged to fund the cleaning. This approach of financing was found to be inefficient on the part of home owners and landlords who had defective or no latrine facilities. Some landlords neglected carrying out repairs on the latrine super structure and emptying filled up pits. This problem was more prevalent among landlords that did not reside with the community. It was observed that such landlords were mainly interested in rental returns and not caring about the status of the latrine. For some landlords, especially those not residing in the community, availability of a public latrine facility in the neighborhood of their rental units served as an excuse for not providing a private latrine. The City Council Public Health staff in Kampala noted that it had become difficult to enforce private latrine ownership because people claimed that they used public facilities even when they actually they did not. Minor operational costs were met in-kind: users/tenants provided their own supplies, e.g. material for anal cleansing, water and soap for hand washing. However, this approach too had many constraints because of lack of social cohesion and shared responsibility. Tenant users generally were reluctant to clean soiled latrines but instead avoided using them. The social behavior of avoiding one another's faeces hindered cleaning of facilities and created conflict among users as observed also among the Akan people in Ghana [36]. The constraints of private financing approach were evidenced by presence of incomplete and/or poorly constructed facilities, prevalent filled up facilities and generally poorly maintained facilities, conflicts between users or with neighbors, adoption of cheaper but unsanitary latrine emptying methods, and other unhygienic methods of excreta disposal such as open defecation around facilities that were found locked, defecating in buckets and pouring into storm drains as well as defecating in plastic bags, which get thrown indiscriminately, consequently being referred to as "flying toilets".

Combined public and private financing: The cost of construction of public facilities under this approach is met almost entirely by third-party providers, such as NGOs (e.g. Plan-Uganda in Bwaise III and WaterAidTanzania in Temeke) or donor or government-funded projects (Kampala Integrated Environmental Management Project-KIEMP and Kampala Urban Sanitation Plan-KUSP in Bwaise III). Third-party providers sometimes cover more than $90 \%$ of investment costs, the remaining costs being the community's contribution in 
various forms such as labour, e.g. carrying materials to construction site, and availing space where to construct the facility. In Temeke, five public VIP latrines were visited: four in Mbagala, one in Tandika. All of these facilities were located in busy areas like markets and bus terminals. Up to $95 \%$ of the investment costs were covered by Temeke Municipal council in collaboration with WaterAid Tanzania. The facilities are operated by the Municipal council and Community Based Organizations and the users pay per visit. In Bwaise III, there were twenty four public facilities and all were visited. The financing approach used and status of operation are summarized in Table 3.

As in the private owned facilities, operation and maintenance costs are met by the users. Users are expected to pay user fees, on a pay-per-visit arrangement to a caretaker. These facilities are required to have a facility user committee to ensure proper operation and maintenance. This approach worked well in public places for example Ddembe market in Bwaise III and at Temeke Hospital. Public facilities in such busy places would get 100 to 200 and above users in a day however, public facilities in less busy places like residential areas did not have as many users. Only about $15 \%$ of households in both study sites used public latrine facilities.

The majority $(85 \%)$ of the residents in Bwaise III and in Temeke used unimproved shared household latrines, which were free and more convenient. This is a major reason for not using public facilities.

Sense of ownership of public facilities located in residential neighborhoods was another challenge mentioned during key informant interviews and focus group discussions. All public latrine facilities in Bwaise III were given as 'hand-outs' from third-party providers, ending up in the hands of landlords who had contributed land for their construction. Although agreements were signed so that landlords permitted public use, for reasons such as misuse of the facility, low collections of user fees to pay a full-time care taker and absence and/or inefficiency of facility user committees, landlords took over the management of the facilities and allocated the stances to specific households (see Table 3). As such, some public facilities became personalized among households, which then contributed towards maintenance of these facilities. At the time of our visit, 3 of the 5 now privatized public latrines were clean and well maintained.

\subsection{Willingness to Pay and Affordability}

User fees for public facilities were paid per visit. The fee structure in Bwaise III was \$0.04 for short or long call (urinate or defecate) and $\$ 0.3$ for bathing while in

Table 3. Financing approaches for public facilities in Bwaise III.

\begin{tabular}{|c|c|c|c|}
\hline $\begin{array}{l}\text { Source of Capital } \\
\text { Investment }\end{array}$ & $\begin{array}{l}\text { Number of } \\
\text { facilities }\end{array}$ & Operation and maintenance & Operational status \\
\hline \multirow[t]{3}{*}{ Plan-Uganda } & 2 & $\begin{array}{l}\text { Public users are very few, users contribute towards emptying } \\
\text { when full }\end{array}$ & Well maintained, clean and still in use \\
\hline & 1 & $\begin{array}{l}\text { Public users are very few, users contribute towards emptying } \\
\text { when full }\end{array}$ & Leaking roof but still in use \\
\hline & 6 & No user fees paid & Pit full, poorly maintained but still in use \\
\hline \multirow[t]{4}{*}{ KIEMP } & 6 & $\begin{array}{l}\text { Public users are very few, users contribute towards emptying } \\
\text { when full }\end{array}$ & Well maintained, clean and still in use \\
\hline & 1 & $\begin{array}{l}\text { Public users are very few, users contribute towards emptying } \\
\text { when full }\end{array}$ & $\begin{array}{l}\text { Public Toilet turned private, clean, well } \\
\text { maintained }\end{array}$ \\
\hline & 1 & $\begin{array}{l}\text { Public users are very few, users contribute towards emptying } \\
\text { when full }\end{array}$ & $\begin{array}{l}\text { Public Toilet turned private, dirty, poorly } \\
\text { maintained }\end{array}$ \\
\hline & 1 & The school management empties the facility when full & $\begin{array}{l}\text { School toilet, dirty, poorly maintained, still in } \\
\text { use }\end{array}$ \\
\hline \multirow[t]{5}{*}{ KUSP } & 1 & $\begin{array}{l}\text { Public users are very few, users contribute towards emptying } \\
\text { when full }\end{array}$ & $\begin{array}{l}\text { Public Toilet turned private, dirty, poorly } \\
\text { maintained }\end{array}$ \\
\hline & 1 & $\begin{array}{l}\text { Public users are very few, users contribute towards emptying } \\
\text { when full }\end{array}$ & $\begin{array}{l}\text { Public Toilet turned private, clean, well } \\
\text { maintained }\end{array}$ \\
\hline & 1 & $\begin{array}{l}\text { Public users are very few, users contribute towards emptying } \\
\text { when full }\end{array}$ & $\begin{array}{l}\text { Public Toilet turned private, clean, well } \\
\text { maintained }\end{array}$ \\
\hline & 1 & $\begin{array}{l}\text { Public users are very few, users contribute towards } \\
\text { emptying when full }\end{array}$ & $\begin{array}{l}\text { Public Toilet, dirty used by both tenants and } \\
\text { the public }\end{array}$ \\
\hline & 1 & Pay per use, generates $\$ 2.5$ daily & Public Toilet, dirty \\
\hline $\begin{array}{l}\text { World vision at } \\
\text { Ddembe market }\end{array}$ & 1 & Pay per use, generates $\$ 3.8$ daily & $\begin{array}{l}\text { Public Toilet (pour flush), clean, well } \\
\text { maintained }\end{array}$ \\
\hline
\end{tabular}


Temeke it was $\$ 0.06$ for short call, $\$ 0.11$ for long call and $\$ 0.11$ for bathing. Although people's willingness to pay for operations and maintenance of public facilities was generally high; $61.2 \%$ in Bwaise III and $75 \%$ in Temeke, it was subject to various factors such as the mode of payment, value for money in terms of quality service received, trust/confidence in the management/sanitary user committee, level of awareness, amount and affordability among others. These factors were analyzed for Bwaise III (Table 4) to determine their association with peoples' willingness to pay for operation and maintenance (O\&M).

From Table 4, respondents who had sanitary facility User committees were almost two times more willing to pay for operations and maintenance of the facilities compared to respondents without User committees. Similarly, respondents who had ever attended sensitization workshops on sanitation issues were almost three times more willing to pay for operations and maintenance of sanitation facilities compared to those that had never attended. This finding is in agreement with other research in Bangladesh [8] where improvements in sanitation were attributed to extensive sensitization and market creation approaches.

A sense of ownership is important for operation and maintenance but is difficult to cultivate among users of a public facility. A facility user committee is meant to oversee the daily operation and maintenance of a facility, either directly by members or indirectly through a caretaker. It also ensures that user fees are collected, securely kept and accounted for. It is observed that a well-functioning facility user committee is a relevant structure in which users can confide and increases their willingness to pay for operation and maintenance. Uganda's water and sanitation sector guidelines recommend that facility user committees comprise of at least seven representatives of users, half of whom should be women [37]. In slum dwellings however, due the transitional nature of tenant residents, user committees often breakup shortly after they are constituted or are not formed at all. The management of such communal/public facilities is taken over by landlords who provided the land on which the facility was constructed. High levels of dissatisfaction with slum life, lack of tenure security and environmental factors such as flooding are some of the reasons for high out-migration in slum areas [38-42].

\subsection{Conclusions}

In light of the socio-economic status, sanitation options, cost involved and the financing approaches used, potential for purely private financing from households is limited. Limitations partly relate to the community structure which comprises on one hand a majority of tenant households with no incentive or mandate to invest and on the other hand landlords often financially constrained to afford costs of providing improved sanitation. Nevertheless, a combination of household financing and other market-based sources such as micro-credit from financial institutions could still be a realistic approach

Table 4. Factors associated with willingness to pay for O\&M in Bwaise III.

\begin{tabular}{|c|c|c|c|c|}
\hline \multirow{2}{*}{ Variable } & \multicolumn{2}{|c|}{ Willingness to pay } & \multirow{2}{*}{ Crude OR } & \multirow{2}{*}{$95 \% \mathrm{CI}$} \\
\hline & No & Yes & & \\
\hline \multicolumn{5}{|c|}{ Emptying of Sanitary facility whenever full } \\
\hline Not done & $17(18.3)$ & $17(13.3)$ & 1 & \\
\hline Done & $76(81.7)$ & $111(86.7)$ & 1.46 & $0.70-3.04$ \\
\hline \multicolumn{5}{|c|}{ Presence of sanitary facility User committee } \\
\hline Not present & $88(84.6)$ & $106(73.6)$ & 1 & \\
\hline Present & $16(15.4)$ & $38(26.4)$ & 1.97 & $1.03-3.77^{*}$ \\
\hline \multicolumn{5}{|c|}{ Having ever attended sensitization workshop } \\
\hline Not attended & $92(90.2)$ & $10(23.6)$ & 1 & \\
\hline Ever attended & $10(9.8)$ & $34(76.4)$ & 2.84 & $1.33-6.07^{*}$ \\
\hline \multicolumn{5}{|c|}{ Amount charged per visit (Short Call) } \\
\hline$\leq \$ 0.04$ & $9(90.0)$ & $87(92.6)$ & 1 & \\
\hline$>\$ 0.04$ & $1(10.0)$ & $7(7.4)$ & 0.72 & $0.72-0.80$ \\
\hline \multicolumn{5}{|c|}{ Amount charged per visit (Long Call) } \\
\hline$\leq \$ 0.04$ & $7(70.0)$ & $64(68.8)$ & 1 & \\
\hline$>\$ 0.04$ & $3(30.0)$ & $29(31.2)$ & 0.94 & $0.26-4.38$ \\
\hline
\end{tabular}

*Statistical significance at $95 \%$ confidence interval, p-values less than 0.05 . 
for investment costs, major repairs and pit emptying. Micro-credits for sanitation enable owners/landlords to meet major costs upfront and pay back over a longer period. Spreading major costs such as investment and pit emptying costs over longer period increases affordability on the part of home owners and allows landlords to pay back the debt in smaller installments using rent money paid by tenants.

The potential for cost recovery is dependent on market size: the more users, the more cost recovery from user fees. This makes public sanitation facilities with many users financially sustainable. It explains why public sanitation facilities with few users in residential neighborhoods are not financially sustainable compared to those with many users. The presence of cheaper or free private sanitation alternatives renders public facilities redundant or for only a few households who can afford.

A sense of ownership attracts private financing. Private shared facilities (although of poor quality) are at least owned by somebody. Ownership of public facilities in residential neighborhoods lies with the community and is symbolized by a facility User committee. Where no facility User committee exists or is non-functional, community's sense of ownership is literally lost and so is the incentive to contribute towards operation and maintenance. A facility user committee motivates private financing, however, due to the transient nature of tenant residents in slums, user committees often breakup or are not formed at all. This calls for revision of ownership arrangements of public latrine facilities and sensitizing the community. The security of tenure on the part of landlords makes them more permanent members of the community. Their active participation in sanitation improvement is necessary for sustainability; however landlords need to be mobilized and organized if they are to act communally. Local authorities are better placed to do such mobilization and monitoring for involvement and participation of landlords. The cost of such interventions could be financed from public funds. Thus a combination of private and public financing is necessary, each to fund different but complementary aspects of sanitation in slums.

\section{ACKNOWLEDGEMENTS}

Funding: This study was supported by Netherlands Ministry of Development Cooperation through the UNESCO-IHE Partnership Research Fund (UPaRF). Grant number FINS: 60041891.

Acknowledgements: The authors are grateful to Klaas Schwartz and Meine Pieter van Dijk for their constructive comments on the manuscript. The research was carried out jointly with UNESCO-IHE, Makerere University, University of Dar es salaam and Kampala City Council in the framework of the Research Project "Addressing the Sanitation Crisis in Unsewered Slum Areas of African Mega-cities" (SCUSA). It has not been subjected to peer and/or policy reviews by the Netherlands Ministry of Development Cooperation and, therefore, does not necessarily reflect their views.

\section{REFERENCES}

[1] Kulabako, N.R., Nalubega, M. and Thunvik, R. (2007) Study of the impact of land use and hydrogeological settings on the shallow groundwater quality in a peri-urban area of Kampala, Uganda. Science of the Total Environment, 381, 180-199. doi:10.1016/j.scitotenv.2007.03.035

[2] Mbuligwe, S.E. and Kaseva, M.E. (2005) Pollution and self-cleansing of an urban river in a developing country: A case study in Dar es Salaam, Tanzania. Environment Manage, 36, 328-342.

[3] United Nations (2005) The Millennium Development Goals Report. United Nations, New York

[4] Van Minh, H. and Nguyen-Viet, H. (2011) Economic aspects of sanitation in developing countries. Environmental Health Insights, 5, 63-70.

[5] WHO/UNICEF (2006) Core questions on drinking-water and sanitation for household surveys. WHO, New York.

[6] Toubkiss, J. (2010) Meeting the sanitation challenge in sub-Saharan cities: Lessons learnt from a financial perspective. In: van Vliet, B., Spaargaren, G. and Oosterveer, P., Eds., Social Perspectives on the Sanitation Challenge, Springer. Netherlands, 163-176. doi:10.1007/978-90-481-3721-3_10

[7] Isunju, J.B., Schwartz, K., Schouten, M.A., Johnson, W.P., and van Dijk, M.P. (2011) Socio-economic aspects of improved sanitation in slums: A review. Public Health, 125, 368-376. doi:10.1016/j.puhe.2011.03.008

[8] Mehta, M. and Knapp, A. (2004) The challenge of financing sanitation for meeting the millennium development goals. In: Low, M., Ed., WSP-Africa, World Bank, Nairobi.

[9] Cairncross, S. (2004) The case for marketing sanitation. In Field Note, Sanitation and Hygiene Series, Water and Sanitation Program-Africa, The World Bank, Nairobi.

[10] Water Aid (2011) Sanitation and water for poor urban communities: A manifesto. Water Aid. http://www.wateraid.org/publications

[11] Castro, J. (2010) Private-sector participation in water and sanitation services: The answer to public sector failures? In: Ringler, C., Biswas, A.K. and Cline, S., Eds., Global Change: Impacts on Water and food Security, Springer, Berlin, 169-193. doi:10.1007/978-3-642-04615-5 9

[12] Mara, D., Lane, J., Scott, B. and Trouba, D. (2010) Sanitation and health. PLoS Medicine, 7, 1-7. doi:10.1371/journal.pmed.1000363

[13] Mason, N., Tucker, J., Kingombe, C. and Kooy, M. (2011) Progress-linked finance: A study of the feasibility and practicality of a proposed WASH financing approach. Water \& Sanitation for the Urban Poor (WSUP) and the Overseas Development Institute (ODI), London, 55.

[14] Trémolet, S., Kolsky, P. and Perez, E. (2010) Financing on-site sanitation for the poor. In: A Six Country Comparative Review and Analysis, Water and Sanitation Pro- 
gram, World Bank, Nairobi.

[15] Thye, Y.P., Templeton, M.R. and Ali, M. (2011) A critical review of technologies for pit latrine emptying in developing countries. Critical Reviews in Environmental Science and Technology, 41, 1793-1819. doi:10.1080/10643389.2010.481593

[16] Wambui, E., Kimani-Murage and Ngindu, A.M. (2007) Quality of water the slum dwellers use: The case of a Kenyan Slum. Journal of Urban Health: Bulletin of the New York Academy of Medicine, $\mathbf{8 4}$.

[17] Sijbesma, C. (2011) Sanitation financing models for the urban poor (thematic overview paper 25). IRC International Water and Sanitation Centre, The Hague.

[18] Fonseca, C., Franceys, R., Batchelor, C., McIntyre, P., Klutse, A., Komives, K., Moriarty, P., Naafs, A., Nyarko, K., Pezon, C., Potter, A., Reddy, R. and Snehalatha, M. (2010) Lifecycle costs approach: Glossary and cost components briefing note 1 . IRC International Water and Sanitation Centre, The Hague.

[19] McGranahan, G. (2002) Demand-side water strategies and the urban poor. IIED, London.

[20] Solo, T.M. (1999) Small-scale entrepreneurs in the urban water and sanitation market. Environment and Urbanization, 11, 117-131. doi:10.1177/095624789901100120

[21] Foster, V. and Briceño-Garmendia, C. (2010) Africa's infrastructure: A time for transformation. World Bank, Washington DC.

[22] Parkinson, J., Tayler, K., Colin, J. and Nema, A. (2008) A guide to decisionmaking: Technology options for urban sanitation in India. Water and Sanitation Program-South Asia, World Bank, New Delhi.

[23] Morella, E., Foster, V. and Banerjee, S.G. (2008) Climbing the ladder: The state of sanitation in sub-Saharan Africa. The World Bank, Washington DC.

[24] Sijbesma, C., Diaz, C., Fonseca, C. and Pezon, C. (2008) Financing sanitation in poor urban areas. IRC Symposium: Sanitation for the Urban Poor Partnerships and Governance, IRC, Delft.

[25] Günther, I., Horst, A., Lüthi, C., Mosler, H.J., Niwagaba, B.C. and Tumwebaze, K.I. (2011) Where do Kampala's poor "go"? An overview of urban sanitation conditions in Kampala's informal settlement areas. In: Policy Brief NCCR-SPLASH, Zürich/Dübendorf, ETH, Zürich.

[26] Pickford, J. and Shaw, R. (1997) Technical brief no. 54: Emptying latrine pits. Waterlines, 16, 15-18. doi:10.3362/0262-8104.1997.044

[27] Schouten, M.A.C. and Mathenge, R.W. (2010) Communal sanitation alternatives for slums: A case study of Kibera, Kenya. Physics and Chemistry of the Earth, Parts A/ $B / C, 35,815-822$. doi:10.1016/j.pce.2010.07.002

[28] Kulabako, N.R., Nalubega, M., Wozei, E. and Thunvik, R. (2010) Environmental health practices, constraints and possible interventions in Peri-urban Settlements: A review of Kampala, Uganda. International Journal of Environmental Health Research, 20, 231-257. doi:10.1080/09603120903545745

[29] Eales, K. and Schaub-Jones, D. (2005) Sanitation partnerships: Landlord or tenant? In: Schaub-Jones, D., Ed.,
The Importance of Rental Relationships to Poor Community Sanitation in 3 African Countries, BPD Sanitation Series, London.

[30] Wageindicator (2010) Minimum wages in Tanzania. WageIndicator Foundation. University of Amsterdam-AIAS. http://www.wageindicator.org/main/minimum-wages/tanz ania

[31] Foxon, K., Buckley, C., Brouckaert, C. and Bakare, B. (2011) How fast do pits and septic tanks fill up? Implications for design and maintenance. Pollution Research Group, UKZN, Durban. http://www.afrisan.org/Pages/Preview.aspx?ItemID=98\& FromURL $=\% 2 \mathrm{fPages} \% 2 \mathrm{fDisplayItem} . \mathrm{aspx} \% 3 \mathrm{fItemID} \%$ 3d98\%26FromURL\%3d\%252fPages\%252fDocuments.as $\mathrm{px} \% 253 \mathrm{f}$

[32] Harvey, P.A. (2007) Excreta disposal in emergencies: A field manual. Loughborough University Water Engineering and Development Centre, Loughborough.

[33] Hanchett, S., Akhter, S., Khan, M.H., Mezulianik, S. and Blagborough, V. (2003) Water, sanitation and hygiene in Bangladeshi slums: An evaluation of the WaterAid-Bangladesh urban programme. Environment and Urbanization, 15, 43-55. doi:10.1177/095624780301500219

[34] Mara, D. (1996) Low-cost urban sanitation. Wiley, Chichester.

[35] Eales, K. (2005) Sanitation partnership series: Bringing pit emptying out of the darkness: A comparison of approaches in Durban, South Africa, and Kibera, Kenya BPD Sanitation Series, London. http://www.bpdws.org/web/d/doc_131.pdf?statsHandlerD one $=$

[36] Jewitt, S. (2011) Geographies of shit: Spatial and temporal variations in attitudes towards human waste. Progress in Human Geography, 35, 608. doi:10.1177/0309132510394704

[37] MWE (2011) Water and sanitation sector district implementation manual. Ministry of Water and Environment, Kampala.

[38] Mudege, N. and Zulu, E. (2011) In their own words: Assessment of satisfaction with residential location among migrants in Nairobi slums. Journal of Urban Health, 88, 219-234. doi:10.1007/s11524-010-9467-z

[39] Zulu, E., Beguy, D., Ezeh, A., Bocquier, P., Madise, N., Cleland, J. and Falkingham, J. (2011) Overview of migration, poverty and health dynamics in Nairobi City's slum settlements. Journal of Urban Health, 88, 185-199. doi:10.1007/s11524-011-9595-0

[40] Nyametso, J. (2011) Resettlement of slum dwellers, land tenure security and improved housing, living and environmental conditions at Madina Estate, Accra, Ghana. Urban Forum, 23, 343-365.

[41] Braun, B. and Aßheuer, T. (2011) Floods in megacity environments: Vulnerability and coping strategies of slum dwellers in Dhaka/Bangladesh. Natural Hazards, 58, 771787. doi:10.1007/s11069-011-9752-5

[42] Osumanu, I. (2007) Environmental concerns of poor households in low-income cities: The case of the Tamale Metropolis, Ghana. GeoJournal, 68, 343-355. doi:10.1007/s10708-007-9088-6 